\title{
Model Penentuan Mahasiswa Berprestasi Dengan Pendekatan Logika Fuzzy
}

\begin{abstract}
ABSTRAK
STMIK Cikarang adalah suatu lembaga pendidikan yang bukan hanya mengajarkan ilmu pengetahuan atau tempat menuntut ilmu tetapi yang sangat penting adalah mendidik mahasiswa/mahasiswi, dalam mendidik tentunya akan mempengaruhi atau dapat merubah tingkah laku, akhlak, kepribadian dan cara berfikir. Dengan pendidikan seharusnya mahasiswa/mahasiswi sebagai pesertadidik bukan hanya memahami atau menguasai ilmu Pengetahuan dan teknologi tetapi juga mempunyai akhlak dan kepribadian yang mulia.

Untuk mewujudkan tujuan pendidikan nasional, yang sejalan dengan visi dan misi STMIK CIKARANG maka perlu memilih seorang mahasiswa yang berprestasi yang akan dijadikan sebagai contoh bagi mahasiswa lainnya dalam proses belajar, tingkah laku, sikap, dan bersosialisasi dalam lingkungan kampus atau luar kampus. Untuk mewujudkan mahasiswa berprestasi tersebut maka unsur pimpinan dan seluruh civitas akademika serta dosen mengadakan rapat untuk membuat kriteria/persyaratan menentukan mahasiswa yang dianggap mampu dan berprestasi.

Untuk menentukan mahasiswa berprestasi diperlukan pendekatan yang dapat dilakukan adalah menggunakan logika fuzzy. Dengan pendekatan tersebut diharapkan mampu memilih mahasiswa berprestasi dengan objektif. Dari kriteria tersebut maka dibuatlah suatu model pendekatan yang digunakan sebagai pendukung keputusan untuk menentukan mahasiswa berprestasi.
\end{abstract}

Key words : Model Pendekatan, Mahasiswa berprestasi, Logika Fuzzy.

\section{A. PENDAHULUAN}

Pendidikan Tinggi adalah suatu lembaga yang bukan hanya mengajar ilmu pengetahuan atau tempat menuntut ilmu tetapi yang sangat penting adalah mendidik mahasiswa atau mahasiswi. Pendidikan tersebut akan mempengaruhi atau dapat merubah tingkah laku, akhlak, kepribadian, cara berfikir, kedewasaan dan lain - lain, karena dengan pendidikan tersebut diharapkan mahasiswa atau mahasiswi sebagai anak didik bukan hanya memahami atau menguasai ilmu dan teknologi tetapi juga mempunyai akhlak dan kepribadian yang baik.

Pendidikan adalah usaha sadar dan bertujuan untuk mengembangkan kualitas manusia. Sebagai suatu kegiatan sadar akan tujuan, maka dalam pelaksanaannya berada dalam suatu proses yang berkesinambungan dalam setiap jenis dan jenjang pendidikan. Semua berkaitan dalam suatu sistem pendidikan yang integral.

Pendidikan sebagai suatu sistem, tidak lain dari suatu totalitas fungsional yang terarah pada suatu tujuan. Setiap sub sistem yang ada dalam sistem tersusun dan tidak dapat dipisahkan dari rangkaian unsur-unsur atau komponen- komponen yang berhubungan secara dinamis dalam suatu kesatuan. (Renstra STMIK CIKARANG, 2010) 
Setiap kampus sebagai lembaga pendidikan juga mempunyai tujuan tersendiri yang disebut tujuan institusional. Tujuan ini disesuaikan dengan jenis dan tingkatan masing- masing kampus. Hasil pencapian dari tujuan institusional ini berwujud dari lulusan yang mampu melaksanakan bidang pekerjaan tertentu atau mampu dididik lebih lanjut menjadi tenaga profesional dalam bidang tertentu dan pada jenjang tertentu pula. Tujuan institusional ini tercantum dalam kurikulum yang menggambarkan secara umum anak didik yang dihasilkan setelah mahasiswa atau mahasiswi menyelesaikan kuliahnya disuatu kampus tertentu. Setiap jenis dan tingkatan lembaga yang berbeda akan menghasilkan anak didik yang berbeda pula, sehingga tujuan institusional kampus perguruan tinggi akan berbeda dengan tujuan institusi kampus yang lainnya .

Dari tujuan nasional dan tujuan institusinal maka membuat visi misi dalam pendidikannya yaitu :

Visi STMIK Cikarang

"Menjadikan STMIK Cikarang sebagai Perguruan Tinggi Swasta (PTS) yang dapat menghasilkan SDM cerdas, inovatif, kreatif, kompetitif dalam bidang teknologi informatika, sistem/manajemen informasi dan komputerisasi akuntansi serta menjunjung tinggi nilai-nilai budaya bangsa"

Misi STMIK Cikarang :

1. Membentuk insan iptek dan imtak juga memiliki bekal kemampuan intelektual dan profesional.

2. Membantu meningkatkan kualitas masyarakat melalui pengembangan dan penerapan ilmu pengetahuan, teknologi informatika dan komputer.

Untuk mewujudkan harapan yang ada dalam pendidikan nasional dan institusional dengan visi-misinya maka kampus sebagai wadah bagi mahasiswa lainnya baik dalam belajar, bertingkah laku, bersosialisasi dengan lingkungan kampus maupun di luar kampus.

\section{B. Identifikasi Masalah}

Penentuan Mahasiswa berprestasi di STMIK Cikarang selama ini masih dilakukan secara konvensional mulai dari pengumpulan nilai, rapat (musyawarah) melibatkan ketua STMIK Cikarang, kaprodi, sekprodi, dosen wali, dosen dan seluruh anggota senat. Cara tersebut masih kurang efisien dan efektif karena masih terdapat ketidakobjektifan penilaian terhadap mahasiswa berprestasi. Oleh karena itu diperlukan metode yang praktis yang dapat diterapkan secara efektif dan efisien. Salah satu pendekatan yang menentukan mahasiswa berprestasi dapat digunakan pendekatan lagika fuzzy. Adapun identifikasi masalah sebagai berikut :

1. Bagaimana cara menetukan mahasiswa berprestasi pada suatu kampus dengan pendekatan logika fuzzy?

2. Bagaimana kondisi sumber daya sistem informasi di STMIK Cikarang untuk menentukan mahasiswa berprestasi saat ini ?

3. Bagaimana menentukan kriteria - kriteria penilaian sebagai bahan acuan untuk penentuan mahasiswa berprestasi di STMIK Cikarang? 
4. Bagaimana strategi untuk mengembangkan sumberdaya sistem informasi penentuan mahasiswa berprestasi pada STMIK Cikarang?

\section{HASIL DAN PEMBAHASAN}

Metode yang digunakan dalam perancangan dan pengembangan suatu aplikasi sistem pendukung keputusan umumnya mengacu pada tahapan pengembangan sistem. Proses perancangan tersebut terdiri dari tujuh tahapan yatu :

1. Menentukan domain persoalan yang akan dipecahkan

Pada tahap ini yaitu menganalisa dan mengumpulkan data serta mempelajari persoalan yang akan dipecahkan. Pelaksanaan tahap ini dapat meningkatkan kemungkinan suksesnya tahap implementasi.

2. Mendefinisikan persoalan

Pada tahap ini, penulis melakukan analisa terhadap persoalan yang akan dipecahkan serta membutuhkan peran seorang ahli yang dapat membantu penyelesaian persoalan

3. Menentukan perangkat keras dan perangkat lunak

Untuk merancang sebuah sistem perlu memperhatikan perangkat lunak dan keras yang akan digunakan. Penentuan perangkat lunak dan perangkat keras merupakan perpersoalan yang saling berhubungan karena akan menentukan hasil yang akan dicapai dalam pembuatan sebuah sistem yang terkomputerisasi.

4. Membangun prototype system

Pada tahap ini analis melakukan perancangan basis data , basis model sistem dialog dan rancangan antar muka pengguna.

5. Menguji dan mengevaluasi model

Pada tahapan ini pengguna harus menguji model dengan suatu contoh persoalan, memperbaikinya bila perlu, dan menganalisis keluaran yang dihasilkan oleh model untuk memastikaan apakah model sudah dapat merepresentasikan persoalan yang dapat dipertanggungjawabkan kebenarannya

6. Menggunakan model

setelah tahap 1 sampai 5 dilaksanakan, maka aplikasi sistem pendukung keputusan siap digunakan pengguna

7. Memelihara sistem

Tahap pemeliharaan sistem termasuk pemeliharaan perangkat lunak dan perangkat keras yang digunakan 


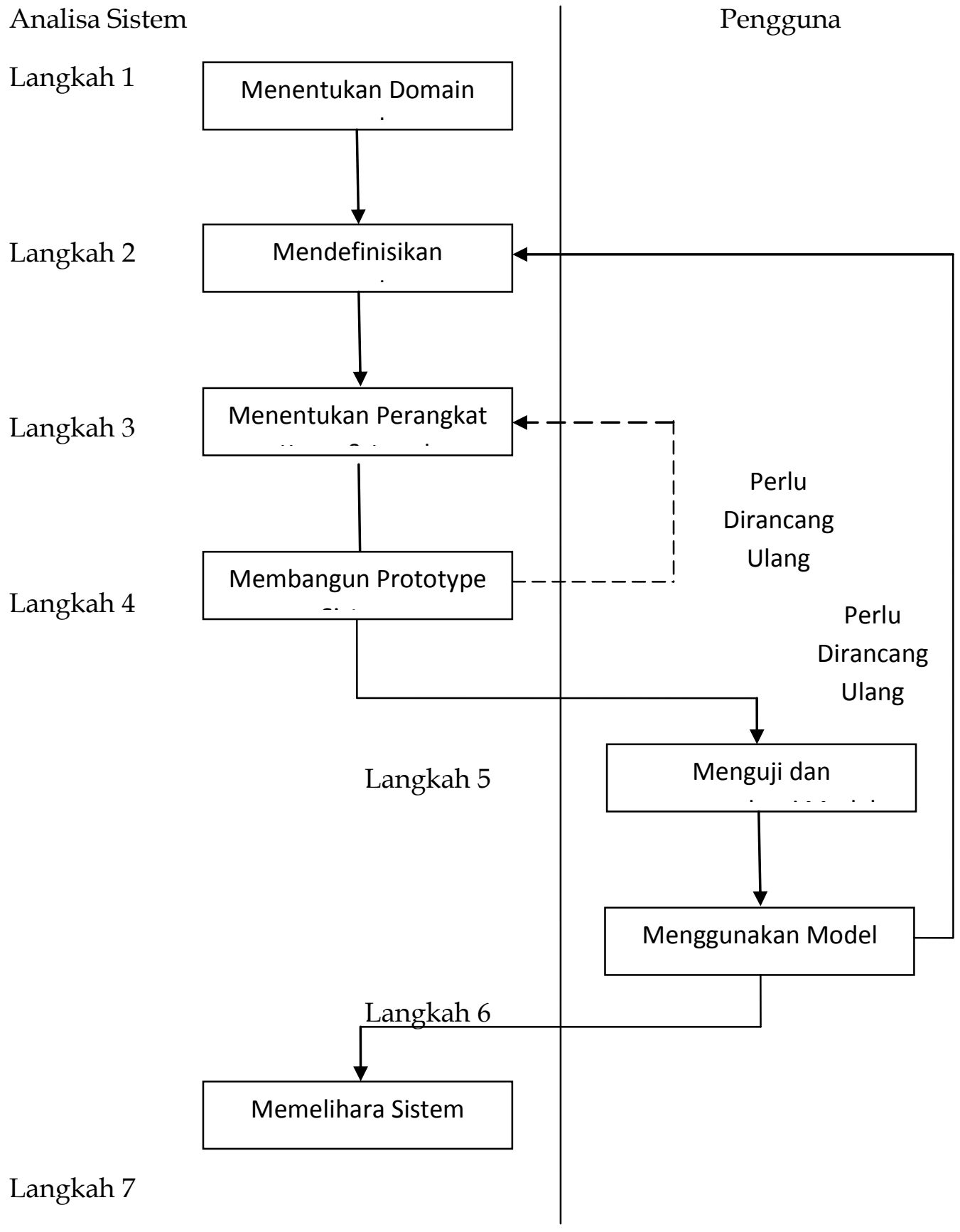

Bagan Alir Pengembangan aplikasi sistem pendukung keputusan

Ada 7 kriteria yang akan dianalisis yang dijadikan variabel fuzzy dalam menentukan mahasiswa berprestasi yaitu :

1. Variabel Sikap

Sikap mahasiswa dan mahasiswi dihitung secara kumulatif berdasarkan bobot poin pelanggaran yang diterapkan pada STMIK Cikarang. Variabel Sikap dibagi menjadi 3 himpunan fuzzy yaitu : BAIK, CUKUP, BURUK. Himpunan fuzzy BAIK akan memiliki domain [0,30] dimana derajat keanggotaan BAIK tertinggi $(=1)$ terletak pada angka $0-15$. Himpunan fuzzy 
CUKUP memiliki domain [20,45] dimana derajat keanggotaan CUKUP tertinggi $(=1)$ terletak pada nilai 30. Himpunan Fuzzy BURUK akan memiliki damain [30.100] dimana derajat keanggotaan BURUK tertinggi $(=1)$ terletak pada nilai $\geq 45$. Variabel Sikap dipresentasikan dengan fungsi keanggotaan bahu dan segitiga seperti Gambar 1 di bawah ini

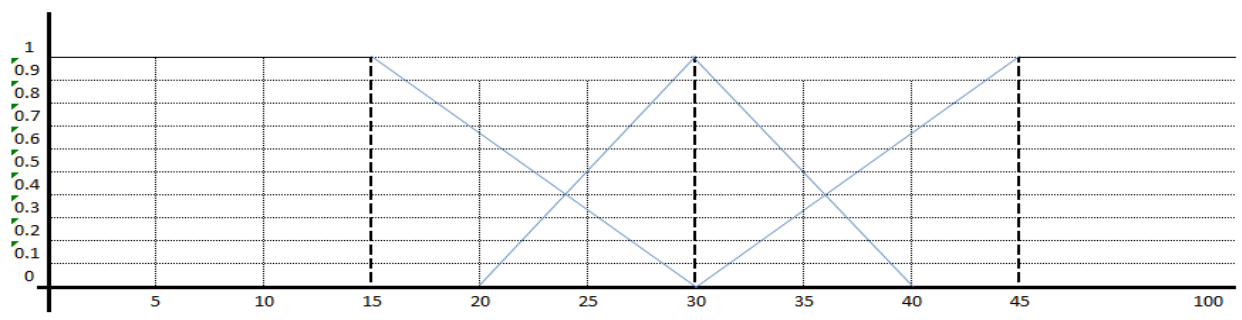

Gambar .1

Himpunan fuzzy untuk Variabel Sikap

Persamaannyaa adalah :

$$
\begin{aligned}
& \mu \operatorname{BAIK}[\mathrm{x}]= \begin{cases}1 ; & x \leq 15 \\
(30-\mathrm{x}) / 15 ; & 15 \leq \mathrm{x} \leq 30 \\
0 ; & x \geq 30\end{cases} \\
& \mu \mathrm{CUKUP}[\mathrm{x}]= \begin{cases}0 ; & \mathrm{x} \leq 20 \text { atau } x \geq 40 \\
(\mathrm{x}-20) / 10 ; & 20 \leq \mathrm{x} \leq 30 \\
(40-\mathrm{x}) / 10 ; & 30 \leq \mathrm{x} \leq 40\end{cases} \\
& \mu \text { BURUK }[\mathrm{x}]= \begin{cases}0 ; & \mathrm{x} \leq 30 \\
(\mathrm{x}-30) / 15 ; & 30 \leq \mathrm{x} \leq 45 \\
1 ; & 30 \geq 45\end{cases}
\end{aligned}
$$

2. Variabel Kedisiplinan

Kedisiplinan mahasiswa dan mahasiswi dihitung secara kumulatif berdasarkan bobob poin pelanggaran yang diterapkan pada STMIK Cikarang. Variabel Kedisiplinan dibagi menjadi 3 himpunan fuzzy yaitu BAIK, CUKUP dan BURUK Himpunan fuzzy baik akan memiliki domain [3,35] dimana derajat keanggotaan BAIK tertingi $(=1)$ terletak pada angka berkisar antara 0 - 20. Himpunan fuzzy CUKUP memiliki domain $25-45$ dimana derajat keanggotaan CUKUP tertinggi $(=1)$ terletak pada nilai 35 . Himpunan fuzzy BURUK akan memiliki domain $[35,100]$ dimana derajat keanggotaan BURUK tertinggi $(=1)$ terletak pada nilai $\geq 50$. Variabel kedisiplinan dipresentasikan dengan fungsi keanggotaan bahu dan segitiga seperti Gambar dibawah ini 


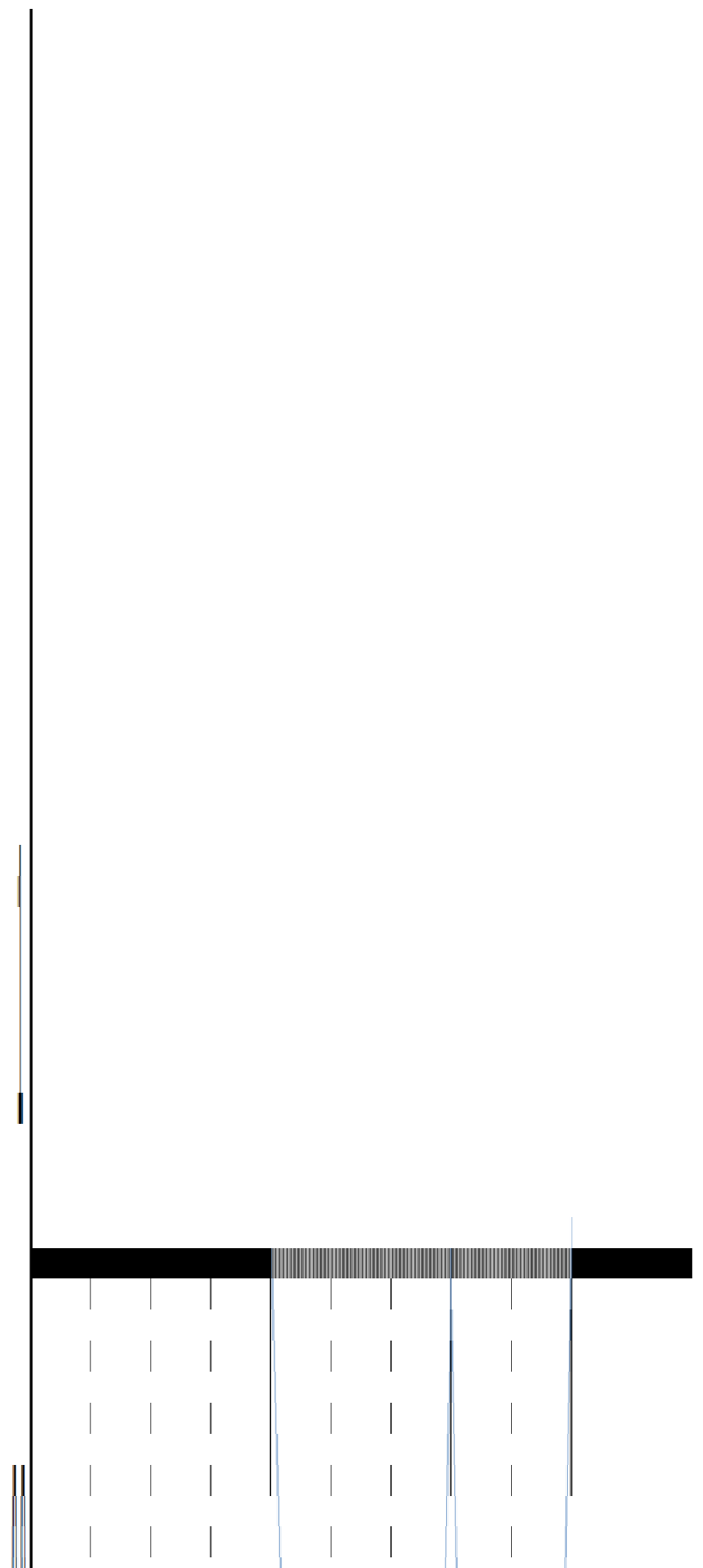


Gambar 2

Himpunan fuzzy untuk Variabel Kedisiplinan

Persamaannya adalah :

$$
\begin{aligned}
& \mu \text { BAIK }[\mathrm{x}]= \begin{cases}1 ; & x \leq 20 \\
(35-\mathrm{x}) / 15 ; & 20 \leq x \leq 35 \\
0 ; & x \geq 35\end{cases} \\
& \mu \text { CUKUP }[\mathrm{x}]= \begin{cases}0 ; & x \leq 25 \text { atau } x \geq 45 \\
(\mathrm{x}-25) / 10 ; & 25 \leq x \leq 35 \\
(45-\mathrm{x}) / 10 ; & 35 \leq x \leq 45\end{cases} \\
& \mu \text { BURUK }[\mathrm{x}]= \begin{cases}0 ; & x \leq 35 \\
(\mathrm{x}-35) / 15 ; & 35 \leq x \leq 50 \\
1 ; & x \geq 50\end{cases}
\end{aligned}
$$

3. Variabel Kerapihan

Kerapihan mahasiswa dan mahasiswi dihitung secara kumulatif berdasarkan bobot poin yang diterapkan pada STMIK Cikarang. Variabel Kerapihan dibagi menjadi 3 himpunan fuzzy yaitu : BAIK, CUKUP dan BURUK. Himpunan fuzzy BAIK akan memiliki domain [0,35] dimana derajat keanggotaan baik tertitertinggi $(=1)$ terletak pada angka 0 - 20. Himpunan fuzzy CUKUP memiliki domain [20,50]. Himpunan fuzzy CUKUP memiliki domain $[20,50]$ dimana derajat keanggotaan CUKUP tertinggi $(=1)$ terletak pada nilai 35 . Himpunan Nilai BURUK tertinggi $(=1)$ terletak pada nilai $\geq 45$. Variabel kerapihan dipresentasikan dengan fungsi keanggotaan bahu dan segitiga seperti ganbar 3 di bawah ini : 
Gambar 3

Himpunan Fuzzy untuk Variabel Kerapihan

Persamaannya adalah :

$$
\begin{aligned}
& \mu \text { BAIK }[\mathrm{x}]= \begin{cases}1 ; & x \leq 20 \\
(35-\mathrm{x}) / 15 ; & 20 \leq \mathrm{x} \leq 35 \\
0 ; & x \geq 35\end{cases} \\
& \mu \text { CUKUP }[\mathrm{x}]= \begin{cases}0 ; & \mathrm{x} \leq 20 \text { atau } x \geq 50 \\
(\mathrm{x}-20) / 15 ; & 20 \leq \mathrm{x} \leq 35 \\
(50-\mathrm{x}) / 15 ; & 35 \leq \mathrm{x} \leq 50\end{cases} \\
& \mu \text { BURUK }[\mathrm{x}]= \begin{cases}0 ; & \mathrm{x} \leq 35 \\
(\mathrm{x}-35) / 15 ; & 35 \leq \mathrm{x} \leq 50 \\
1 ; & x \geq 50\end{cases}
\end{aligned}
$$

4. Narkoba dan obat terlarang

Narkoba dan bahan terlarang dihitung secara kumulatif berdasarkan bobot poin pelanggaran yang diterapkan pada STMIK Cikarang. Variabel Narkoba dan BarangTerlarang dibagi menjadi dua himpunan fuzzy yaitu: TIDAK TERLIBAT dan TERLIBAT himpunan fuzzy tidak terlibat akan memiliki domain $[0,30]$ dimana derajat keanggotaan BAIK tertinggi $(=1)$ terletak pada angka 0. Himpunan fuzzy TERLIBAT memiliki domain [20,100] dimana derajat keanggotaan TERLIBAT tertinggi $(=1)$ terletak pada nilai $\geq 80$. Variabel Narkoba dan Barang Terlarang dipresentasikan dengan fungsi keanggotaan bahu dan segitiga seperti Gambar 4 di bawah ini 


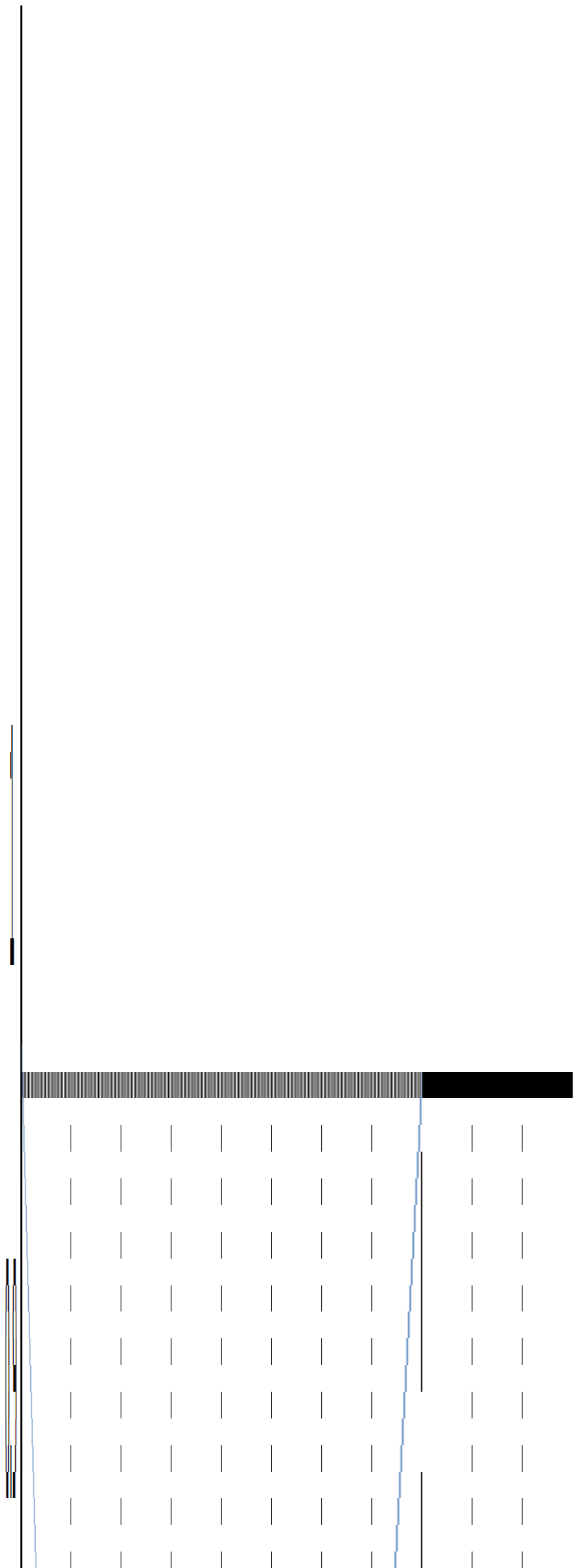




\section{Gambar 4}

Himpunan fuzzy untuk variabel Narkoba dan Barang Terlarang Persamaannya adalah :

5. Variabel rata - rata nilai IPK

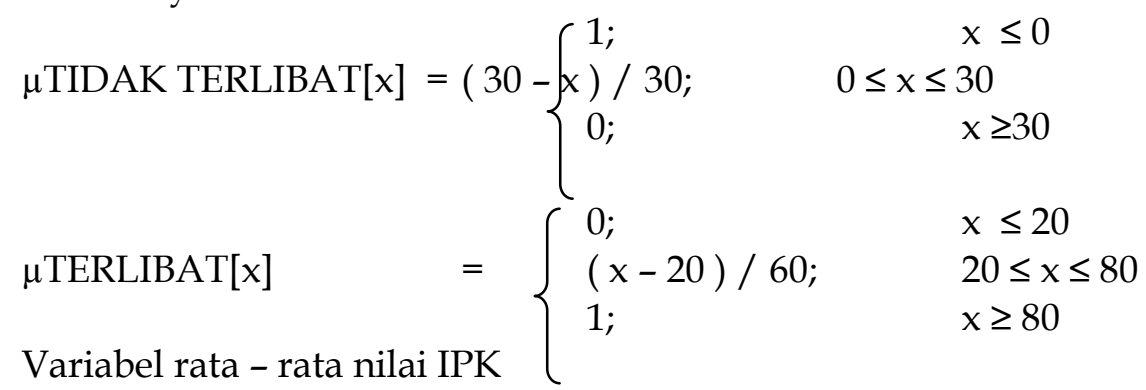

Nilai IPK diambil dari rata- rata total nilai keseluruhan. Variabel Nilai IPK dibagi menjadi 3 himpunan fuzzy yaitu: BURUK, CUKUP, BAIK. Himpunan fuzzy BURUK akan memiliki domain $[0,6.5]$ dimana derajat keanggotaan BURUK tertinggi $(=1)$ terletak antara angka 0 - 5.5. himpunan fuzzy CUKUP memiliki domain [6.8] dimana derajat keanggotaan CUKUP tertinggi $(=1)$ terletak pada nilai 7. Himpunan fuzzy BAIK akan memiliki domain $[6.5,8]$ dimana derajat keanggotaan BAIK tertinggi $(=1)$ tertetak pada nilai 8 sampaii 10. Variabel nilai rata - rata IPK dipresentasikan dengan fungsi keanggotaan bahu dan segitiga seperti gambar 5 di bawah ini: 


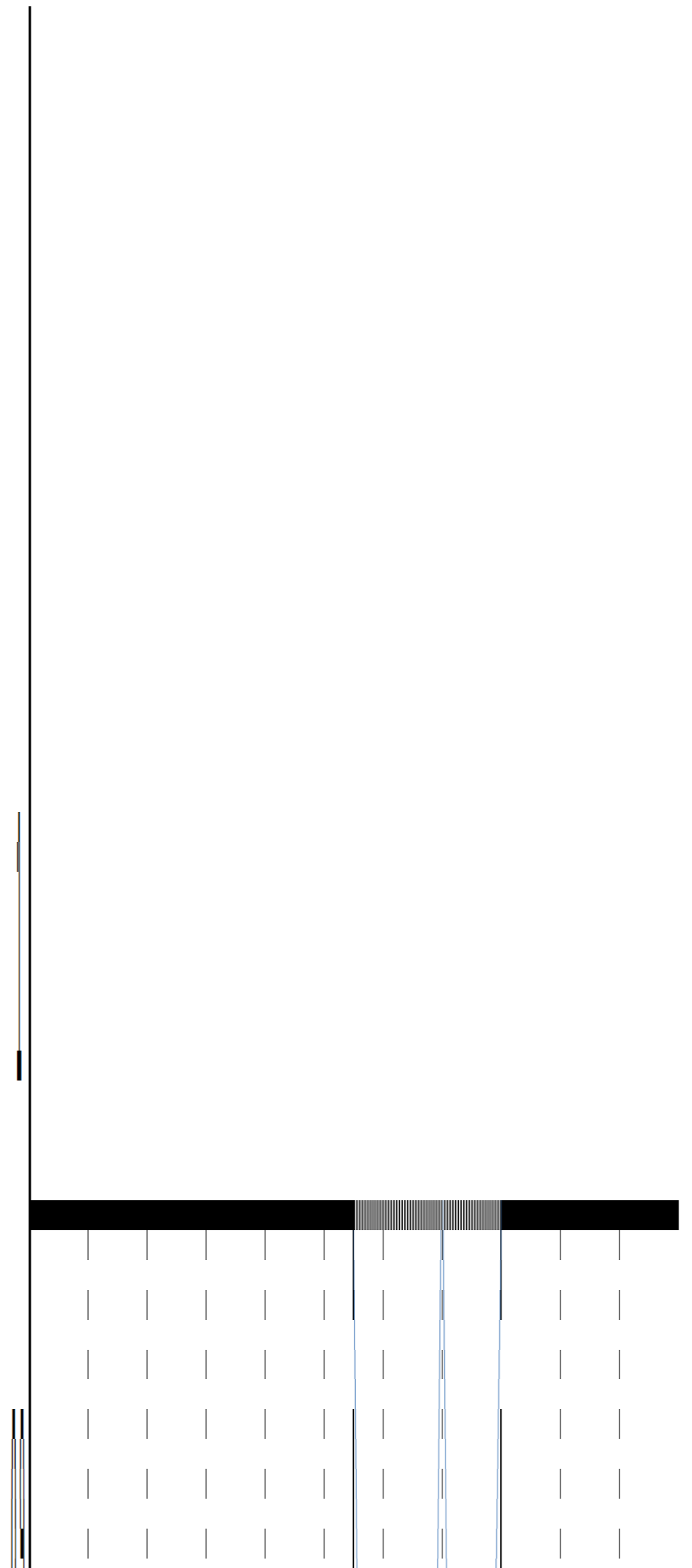


Gambar 5

himpunan fuzzy untuk Variabel IPK

$$
\begin{aligned}
& \mu \text { BAIK }[x]= \begin{cases}0 ; & x \leq 6.5 \\
(x-6.5) / 1.5 ; 6.5 \leq x \leq 8 & x \geq 8\end{cases} \\
& 1 ; \\
& \mu \text { CUKUP }[x]= \begin{cases}0 ; & x \leq 6 \text { atau } x \geq 8 \\
(x-6) ; & 6 \leq x \leq 7 \\
(8-x) ; & 7 \leq x \leq 8\end{cases} \\
& \mu \text { BURUK }[x]= \begin{cases}1 ; & x \leq 5.5 \\
(6.5-x) ; & 5.5 \leq x \leq 6.5 \\
0 ; & x \geq 6.5\end{cases}
\end{aligned}
$$

6. Variabel Nilai Praktek Kerja Lapangan

Nilai kerja praktek lapangan diambil dari sertifikat praktek kerja lapangan. Praktek kerja lapangan hanya ada pada semester 6 . Variabel kerja praktek lapangan dibagi menjadi 3 himpunan fuzzy yaitu BAIK, CUKUP, BURUK. Himpunan fuzzy BURUK akan memiliki damain $[0,6.5]$ dimana derajat keanggotaan BURUK tertinggi $(=1)$ terletak pada angka 0 - 5.5. himpunan fuzzy CUKUP memiliki domain [6,8.5] dimana derajat keanggotaan CUKUP tertingg $(=1)$ terletak pada nilai 7. Himpunan fuzzy BAIK akan memiliki domain [6.5,8.5] dimana derajat keanggotaan BAIK tertinggi $(=1)$ terletak pada nilai 8.5 sampai 10. Variabel praktek kerja lapangan dipresentasikan dengan fungsi keanggotaan bahu dan segitiga seperti pada Gambar 6 di bawh ini : 


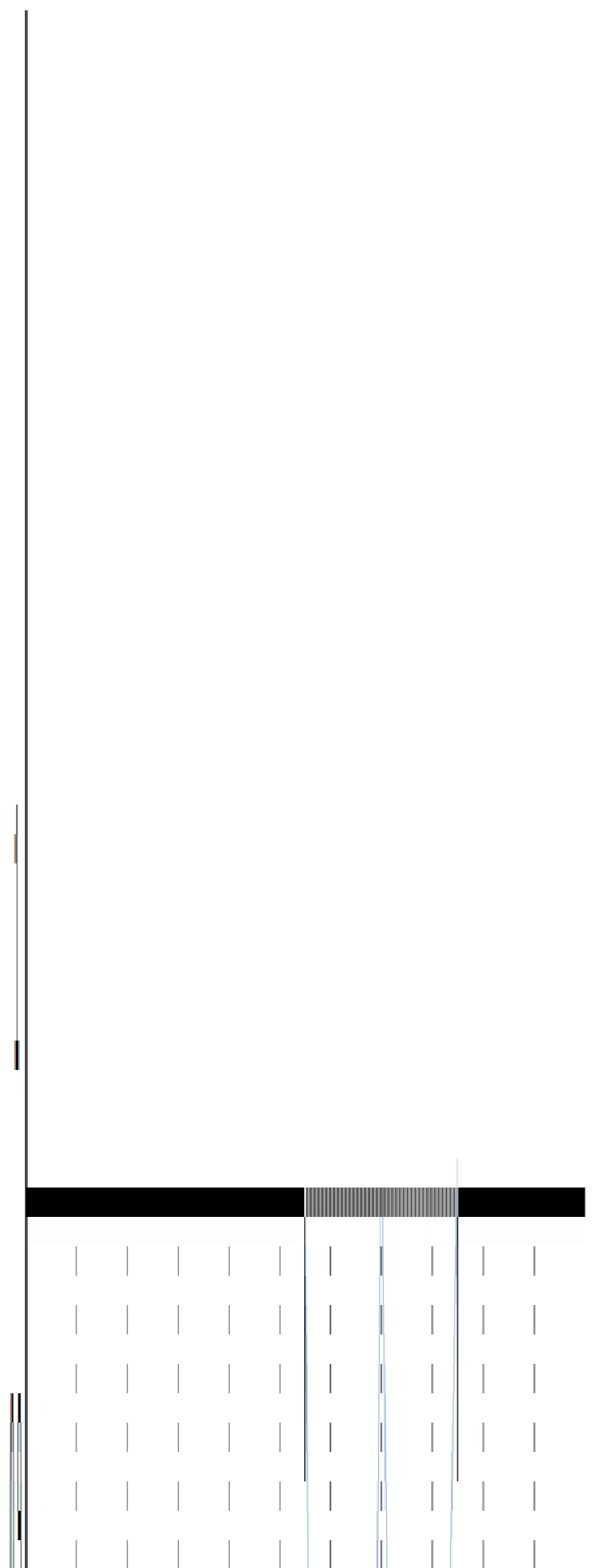


Gambar 6

Himpunan fuzzy untuk variabel Nilai Praktek Kerja Lapangan Persamaannya adalah :

$$
\begin{aligned}
& \mu \mathrm{BAIK}[\mathrm{x}]= \begin{cases}0 ; & x \leq 6.5 \\
(\mathrm{x}-6.5) / 2 ; & 6.5 \leq x \leq 8.5 \\
1 ; & x \geq 8.5\end{cases} \\
& 1 ; \quad x \geq 8.5 \\
& \begin{cases}0 ; & x \leq 6 \text { atau } x \geq 8\end{cases} \\
& \mu \mathrm{CUKUP}[\mathrm{x}]= \begin{cases}(\mathrm{x}-6) ; & 6 \leq \mathrm{x} \leq 7\end{cases} \\
& (8-x) / 1,5 ; \quad 7 \leq x \leq 8,5 \\
& \mu \operatorname{BURUK}[x]= \begin{cases}1 ; & x \leq 5.5 \\
(6.5-x) ; & 5.5 \leq x \leq 6.5\end{cases} \\
& 0 ; \quad x \geq 6.5
\end{aligned}
$$

7. Variabel Organisasi

Nilai organisasi diambil dari data kegiatan kampus yang disimpan oleh pembantu ketua III bidang kemahasiswaan, minimal dalam satu tahun kampus mengadakan kegiatan sebanyak 4 kali. Jadi dalam 3 tahun minimal kegiatan kampus sebanyak 12 kali kegiatan. Variabel Organisasi dibagi menjsdi 2 himpunan fuzyy yaitu TIDAK AKTIF dan AKTIF. himpunan fuzzy TIDAK AKTIF akan memiliki domain [0,4] dimana derajat keanggotaan TIDAK AKTIF tertingi $(=1)$ terletak pada angka 0 - 1 . Himpunan fuzzy AKTIF akan memiliki [2.14] dimana derajat keanggotaan AKTIF tertinggi terletak pada nilai 4 sampai 14 . Variabel organisasi 
dipresentasikan dengan fungsi keanggotaan bahu dan segitiga Gambar 7 di 


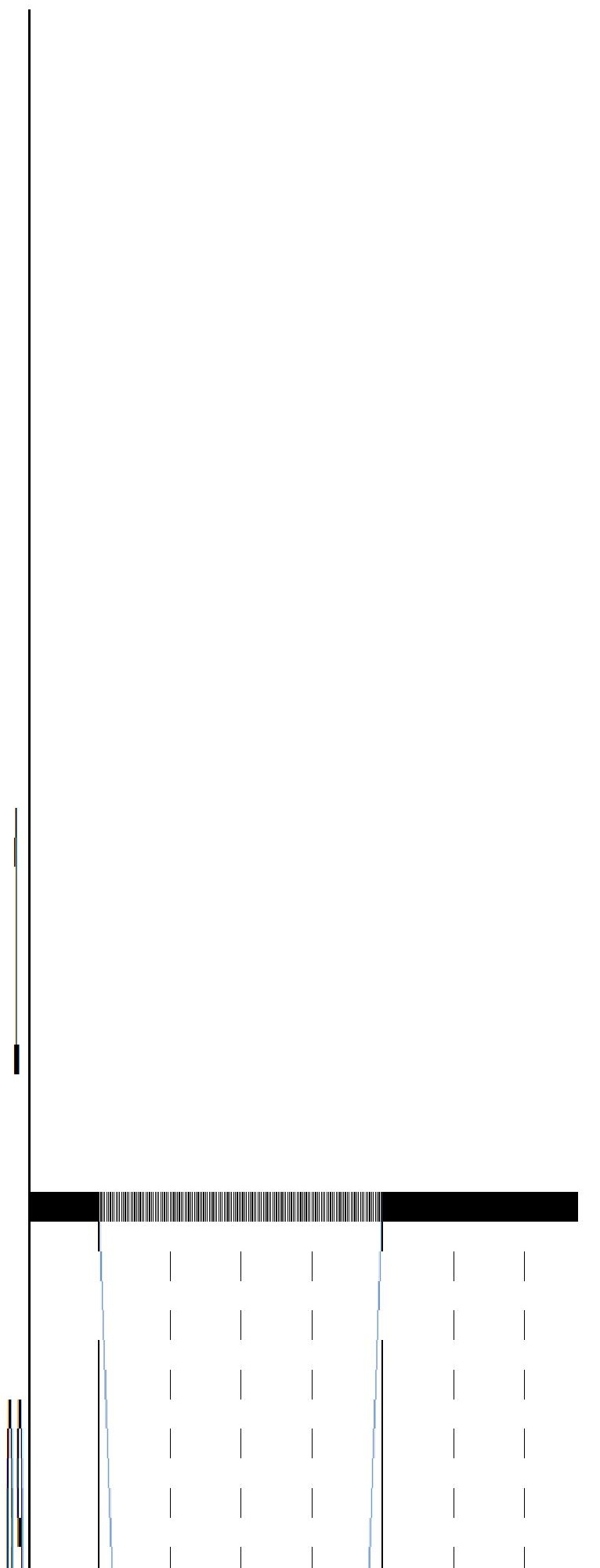




\section{Gambar 7}

Himpunan fuzzy untuk Variabel Organisasi

Persamaannya adalah :

$$
\begin{aligned}
& \mu \operatorname{TIDAK} \text { AKTIF }[\mathrm{x}]= \begin{cases}1 ; & \mathrm{x} \leq 1 \\
(4-\mathrm{x}) / 3 ; & \\
05 ; & \mathrm{x} \geq 4\end{cases} \\
& \mu \mathrm{AKTIF}[\mathrm{x}]= \begin{cases}0 ; \\
\mathrm{x}-2) / 3 ; & \mathrm{x} \leq 2 \\
1 ; & 2 \leq \mathrm{x} \leq 5 \\
& \mathrm{x} \geq 5\end{cases}
\end{aligned}
$$

Desain Output Proses data fuzzy kriteria per item

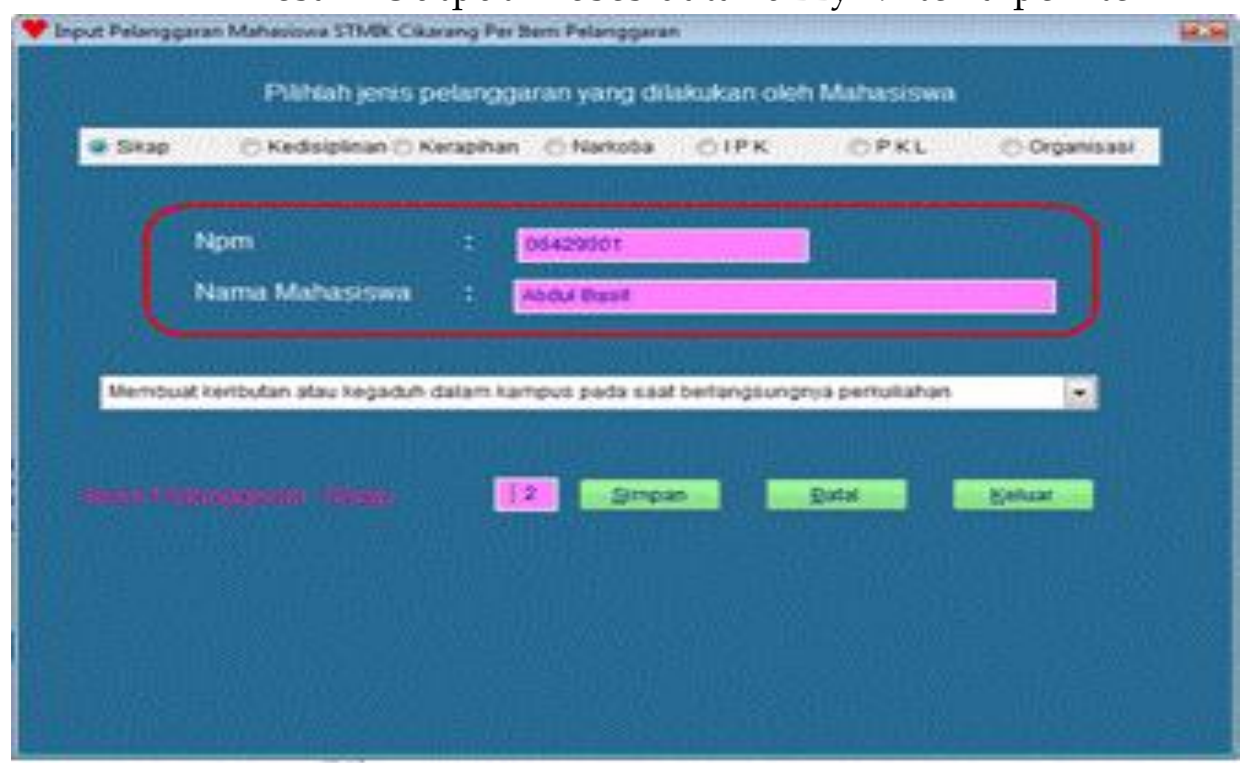

Gambar 8

Output Proses Data Fuzzy 


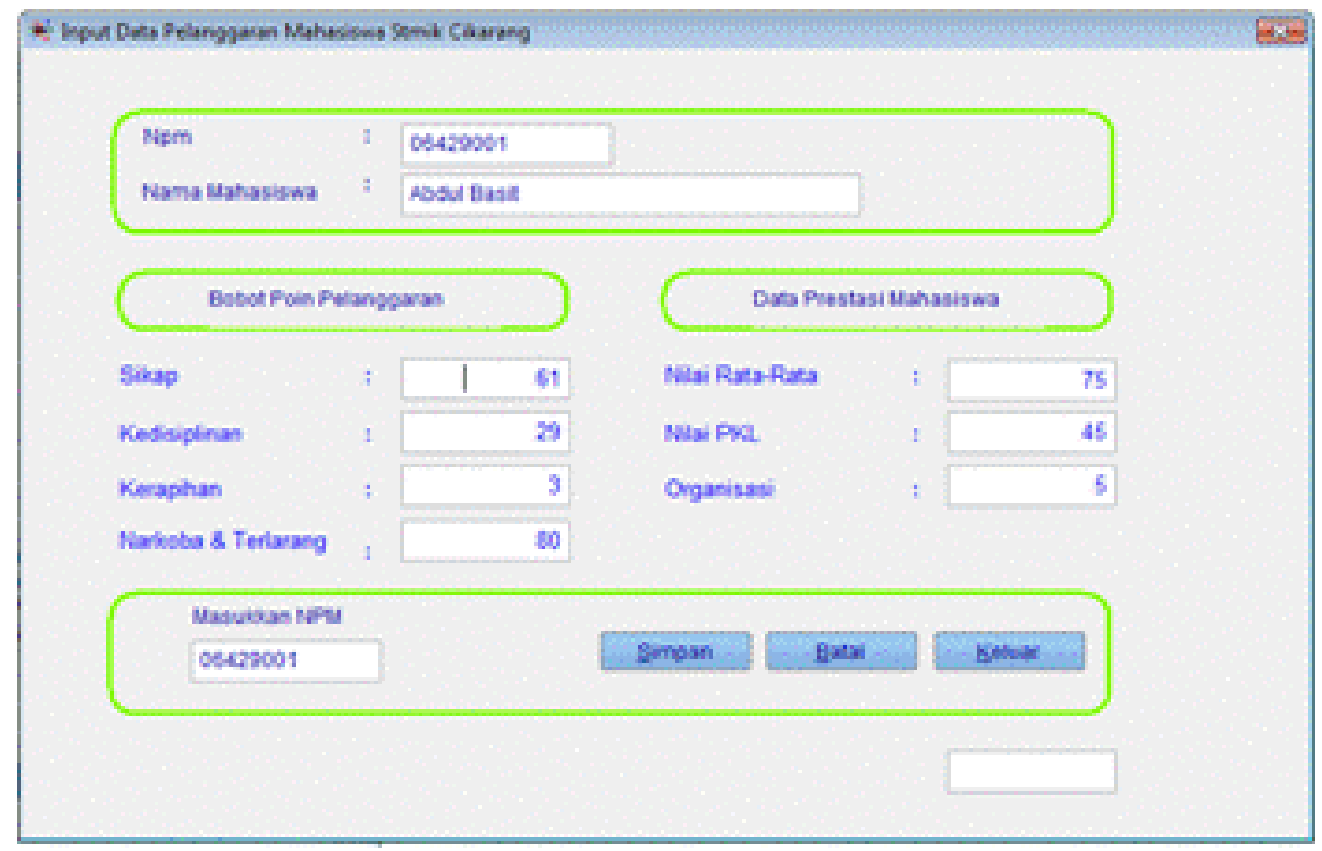

Gambar 9

Output Proses Penghitungan Fire Strength

Rekomendasi Mahasiswa Berprestasi

Pada tahap ini adalah tahap proses menentukan mahasiswa berprestasi dengan melihat fire strength terbesar dari himpunan fuzzy setiap mahasiswa. Sistem memberi batasan untuk menentukan mahasiswa berprestasi dengan nilai fire strength harus lebih besar sama dengan 0.6. Jika nilai fire strength dibawah 0.6 maka tidak ada mahasiswa berprestasi

Desain Output rekomendasi siswa teladan dapat dilihat pada Gambar 10 


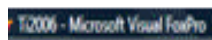

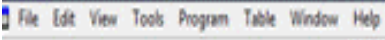

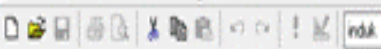

문ำ

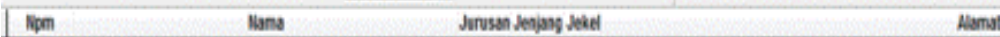

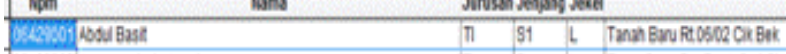

\begin{tabular}{|c|c|c|c|}
\hline 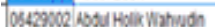 & $\pi$ & 89 & \\
\hline
\end{tabular}

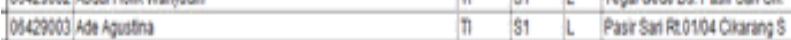

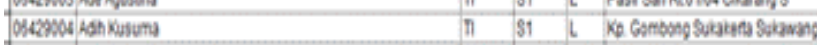

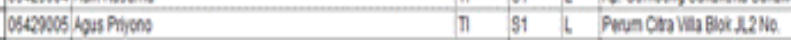

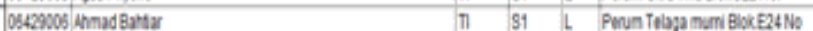

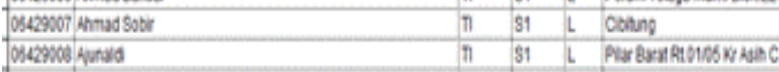

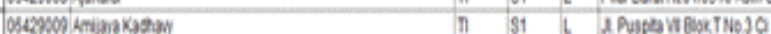

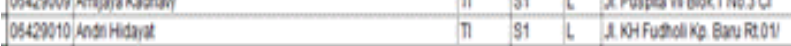

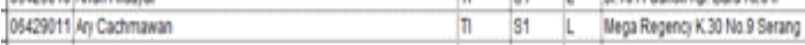

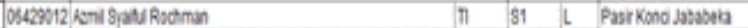

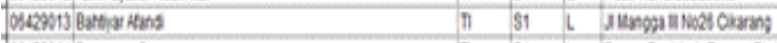

Dosawit bantang Gunama

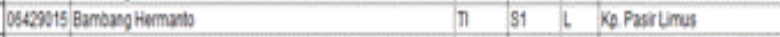

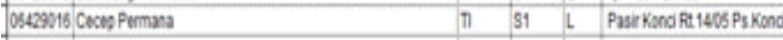

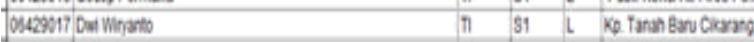

OStratiogenas

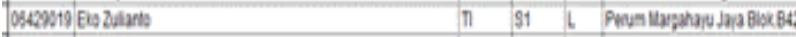

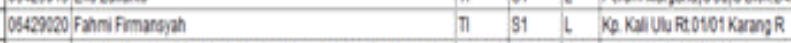

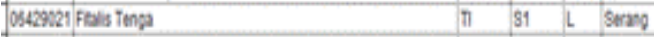

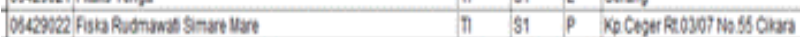

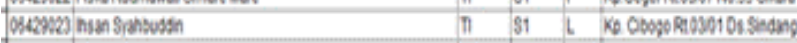

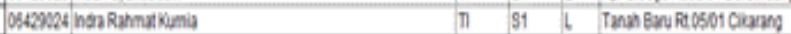

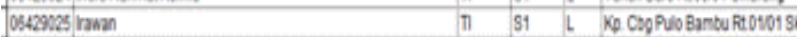

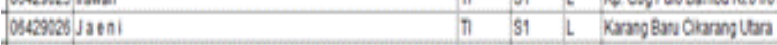

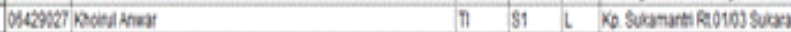

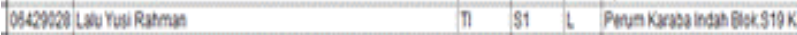

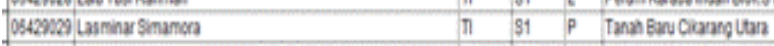

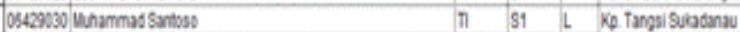

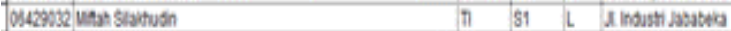

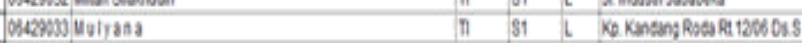

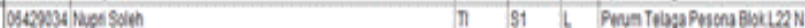

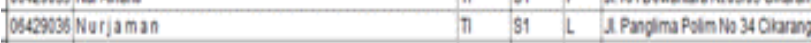

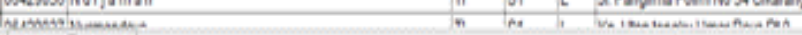

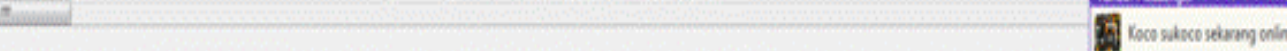

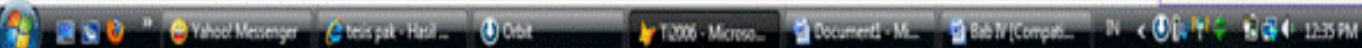




\section{Kesimpulan}

1. Penentuan mahasiswa berprestasi di STMIK CIKARANG dapat dibangun dengan pendekatan logika fuzzy.

2. Penentuan mahasiswa berprestasi dengan pendekatan logika fuzzy lebih objektif dari pada penentuan mahasiswa berprestasi dengan cara konvensional

3. Penentuan mahasiswa berprestasi dengan pendekatan logika fuzzy lebih efisien.

4. Penentuan mahasiswa berprestasi dengan pendekatan logika fuzzy dapat menekan biaya operasional kampus STMIK CIKARANG

5. Penentuan mahasiswa berprestasi dengan pendekatan logika fuzzy menggunakan 7 kriteria dalam menentukan keputusan

6. Strategi untuk mengembangkan sumber daya sistem informasi penentuan mahasiswa berprestasi dengan pendekatan logika fuzzy lebih transparan karena mahasiswa dapat langsung mengakses data yang diperlukan

\section{E. DAFTAR PUSTAKA}

Arif Imam Suroso, Rini Muliahati, " Sistem Rekrutmen Berbasis Fuzzy ", Jurnal ilmiah - Ilmu Komputer. Vol 3 No 1, Mei 2005. 61 - 75.

Efraim Turban, Jay E. Aronson, Tina - Peng Liang, " Decision Support Systems And Intelligent Systems $-7^{1}$ Ed ", Pearson Education, Inc. Upper Saddle River, New Jersey, 2005.

Klir, G.J. \& Bo Y. " Fuzzy Sets and Fuzzy Logic, Theory and Applications ". PrenticeHall, New Jersey, 1995.

Kelornpok Kerja Senat Dosen STMIK CIKARANG, " Buku Pedoman Akademik Tahun Akademik 2008 /2009", 2008.

Kelornpok Kerja Senat Dosen STMIK CIKARANG, " Petunjuk Pelaksana Bimbingan Pcnyuluhan/Bimbingan Konseling STMIK CIKARANG", 2008.

Marimin, "Teknik Dan Aplikasi Pengambilan Keputusan Kriteria Majemuk ", Cetakan 1, Grasindo, Jakarta, 2004.

Marimin, " Teori dan Aplikasi Sistem Pakar Dalam Teknologi Manajerial ", Edisi ke 2, IPB Press, Bogor, 2005.

Racth, P.G, " Expert System: a Software Methodology For Modern Applications", IEEE Computer Society Press Los Alamitos, California, 1990. 
Sri Kusumadewi, " Analisis \& Desain Sistem Fuzzy menggunakan Tool Box Matlab", Graha Ilmu Yogyakarta, 2002.

Sri Kusumadewi dan Hari Purnomo, " Aplikasi Logika Fuzzy Untuk Pendukung Keputusan", Graha Ilmu Yogyakarta, 2004.

\section{BIODATA DIRI}

$\begin{array}{ll}\text { Nama } & : \text { Ahmad Jazuli } \\ \text { NIDN } & : 0406107004 \\ \text { Jurusan } & : \text { Teknik Informatika } \\ \text { Fakultas } & : \text { Teknik } \\ \text { Universitas } & : \text { Universitas Muria Kudus (UMK) } \\ \text { Email } & \text { : ajay@umk.ac.id } \\ \text { Publikasi Sebelumnya } & :-\end{array}$

